\title{
A ELTE Egyetemi Könyvtár Vergerio-grammatikája (Cod. Lat. 23) ${ }^{1}$
}

A könyvtár 2008-as katalógusa², valamint az Egyetemi Könyvtár 2008-as Mátyás király. Magyarország a reneszánsz hajnalán címü kiállítás katalógusának Wehli Tünde által jegyzett, e kódexre vonatkozó leírása kiválóan összegzi a „Vergerio-grammatika” legfontosabb adatait. Az említett müvek a kódex 1877es Magyarországra visszaérkezésekor készített első Csontosi János-féle leírásra, ${ }^{3}$ és az azóta végzett kutatásokra alapozva foglalják össze a kisméretű (192x130 $\mathrm{mm}), 108$ foliót tartalmazó könyv ismérveit. ${ }^{4}$ Pier Paolo Vergerio, ${ }^{5}$ mint feltételezett (meg nem nevezett) possessor azonosítása egy paleográfiai összevetés eredménye, amelyet Csapodiné Gárdonyi Klára végzett el a kódex f 108v-n található két sor (,,A. d. M.CCCC.XL. fui infirmus ad mortem, quod numquam per antea talem infirmitatem fui passus.") és Vergeriónak a velencei Biblioteca

${ }^{1}$ A tanulmány elkészítésében kapott segítségért szeretnék itt köszönetet mondani Cséka Györgynek és Cser Andrásnak.

${ }^{2}$ Catalogus codicum latinorum medii aevi Bibliothecae Universitatis Budapestinensis. Revisus et auctus per Petrum Tóth. Budapest, ELTE Egyetemi Könyvtár. 2008. http://hdl.handle. net/10831/32258 (2017. január 23.)

${ }^{3}$ Csontosi János: A Konstantinápolyból érkezett corvinák ismertetése. = Magyar Könyvszemle, 1877. 3-4, sz. 157-218. p.

${ }^{4}$ Tóth Péter im. 34-35. p.; Wehli Tünde: Latin nyelvkönyv - Pier Paolo Vergerio bejegyzésével. $=$ Mátyás király. Magyarország a reneszánsz hajnalán. Kiállítás az Egyetemi Könyvtárban, 2008. május 20. - június 21. Szerk. Bibor Máté János. Budapest, ELTE Egyetemi Könyvtár. 2008. 13. p.

${ }^{5}$ Pier Paolo Vergerio személyéröl és a magyar humanizmus születésében betöltött szerepéről: Banfi, Florio: Pier Paolo Vergerio il Vecchio in Ungheria, Archivio della Società Mattia Corvino (Supplemento a Corvina). = Corvina rivista di scienze, lettere ed arti della Societa unghereseitaliana Mattia Corvino, 3. évf. 1940. 1. sz. 1-30. p.; Huszti József: Pier Paolo Vergerio és a magyar humanizmus kezdete. $=$ Filológiai Közlöny, 1. évf. 1955.4. sz. 521-533. p.; Pajorin Klára: A magyar humanizmus Zsigmond-kori alapjai. = Mủvészet Zsigmond király korában, 1387-1437. Tanulmányok. Szerk. Beke László, Marosi Ernő, Wehli Tünde. Budapest, Művészettörténeti Kutatócsoport. 1987. 193-211. p.; Uő.: Mátyás király és a humanista nevelés. = Vigilia, 55. évf. 1990. 11. sz. 824-827. p.; Uő.: Vitéz János műveltsége. = Irodalomtudományi Közlemények, 108. évf. 2004. 5-6. sz. 533-540. p.; Solymosi Milán: Pier Paolo Vergerio e Coluccio Salutati. = Verbum, 4. Budapest, Akad. K., 2002. 147-163. p.; Kiss Farkas Gábor: A magyarországi humanizmus kezdeteiröl. Pierpaolo Vergerio, Vitéz János és Johannes Tröster. = Convivium Pajorin Klára 70. születésnapjára, Debrecen, 2012. 119-131. p.; Lengyel Réka: Egy Petrarcának tulajdonított Vergerio-hely a Szalkaikódexben, 1489/90 = Convivium Pajorin Klára 70. születésnapjára. Debrecen, 2012. 143-146. p.

Vergerio leveleinek kiadása: Pier Paolo Vergerio: L'Epistolario di Pier Paolo Vergerio, a cura di Leonardo Smith. Roma, 1934.

Pedagógiai mủvének legutóbb megjelent angol fordítása: Kallendorf, Craig W.: Humanist educational treatises. (The I Tatti Renaissance Library, 5). Cambridge, Harvard University Press. 2002. 
Nazionale di San Marco, Lat. Cl. XIV kötetében, az 54. fol. 101, 101 b helyen található írása között. Amint Csapodiné is megjegyzi azonban, ez az írás közel ötven évvel korábbi az 1440-es két sornál, tehát az identifikáció nem áll teljesen biztos lábakon. A megállapítás, miszerint ,,minthogy Vergerio 1444-ben halt meg, ez a négy évvel elöbbi közlés súlyos betegségéröl indokolt lehet" szorosan véve ugyancsak nem bizonyítja az olasz (isztriai) humanista és a könyv kapcsolatát. ${ }^{6}$

A másik, Vergerio possessor volta mellett felhozott érv a kódexben, a $\mathrm{f}$ 104v-n található levéltöredék, amelynek teljes átírását is megadja a katalógus: „Reuerende pater et domine mi, humiliter recommendo me vestre paternitati. Post humilem recomendacionem propositum notifico ad presens quod bene ualeo gracia saluatoris, quod idem affecto de vestra dominacione. Pridem superuenit filius vester presbiter Johannes quem affectuose interrogatus fui de uestra paternitate, qui nunciauit bonum nouum de vobis quod bene stabatis, quod summo fui alacer et in corde meo, per veritatem sublimam (sic) putabam uos vidisse istius (sic) diebus oculis corporis, ${ }^{7}$ sed fuit obstacio aliqua que constrinxit terminos ita quod ad presens non peregi quo tendebam, scilicet ${ }^{8}$ ad vos Carissime Domine quo intendebam vobiscum proferre de noue et nunquam audite alias. Sed huic est ad presens declinare aures vestras et intelligatis sane ut narrarem de nouis uerissimis. Et primo quantum ad congregacionem tocius concily generalis Constancie celebrati. Quod ibi sit totus mundus, quantum ad nobilitatem scienciam, prudenciam..."

A levélnek tehát sem a küldőjét, sem a címzettjét nem ismerjük, az egyetlen személy, akit névvel említ - Johannes presbiter -, nem azonosítható. A konstanzi zsinat (1414-1418) egykorú eseményként említése segít a datálásban, de nem kapcsolódik valójában ahhoz a tényhez, hogy Vergerio itt találkozott Luxemburgi Zsigmond királlyal, aki ezt követően Budára hívta.

Pajorin Klára Vergerio testamentumát elemezve megmutatta, hogy számos görög és latin könyvet is hátrahagyott, de ez az adat sem visz minket közelebb ahhoz a kérdéshez, hogy ez a kódex vajon valóban része volt-e az ő személyes könyvtárának.

A kódex tartalma latin grammatika, ami szintén nem személyes mü, hanem nyilvánvalóan tömegesen másolták. A felépítése és a szerkezete igazodik a korabeli latintanítás módszertanához: prózában és versben is memoriternek szánt szabályokat, és sokhelyütt a szabályos és szabálytalan alakok felsorolását tartalmazza. Itt kap szerepet egy közvetító nyelv, amelyet a jelen tanulmány igyekszik behatárolni.

${ }^{6}$ Csapodiné Gárdonyi Klára: A budapesti Egyetemi Könyvtár korvinái. = Magyar Könyvszemle, 1981. 3. sz. 224. p.

${ }^{7}$ A helyes olvasat: corporeis, bár ez nem változtat semmit.

${ }^{8}$ silicet.

${ }^{9}$ quia 
Az egyes szófajoknak és azon belüli kategóriáknak a grammatika hasábjain történő tárgyalását a véletlenszerủen kiválasztott $\mathrm{f} 95 \mathrm{v}$ lap alapján mutatom be. Itt az $i$-tövü fönevek ragozása szerepel: a lap tetején azokkal a fónevekkel kezdi a szerző a magyarázatot, amelyek singularis nominativus alakja -im-re végződik. Ezt egy hexameterből, minden bizonnyal valamelyik közkedvelt késő középkori verses grammatikából (Alexander de Villa Dei, Eberhardus Bethuniensis, Johannes Balbus) vette át. Az első három sorban közneveket sorol fel: vim, burim, pelvim, sitim, tussimque, caribdim..., aztán hozzáteszi, hogy vannak tulajdonnevek és görög jövevényszavak is: his qu(a)edam propria sociantur paucaque graeca / ut Tigrim Tibrim Tripolim Sirtimque eclipsim... majd megjegyzi, hogy ezek sem mindig követik a szabályt: inveniens turem verumtamen atque securem l et pelvem navem pupem testem quoque clavem. Itt következik a vis szó elragozása: Nominativo hec vis. Acusativo hanc vim. Ablativo ab hac vi. Et non habet plures casus in singulari, és ugyanezt megtoldja egy verssel: Vis vim vique dabit totum plurale tenebit. Miután ezt megtette, felsorolja ugyanazokat a föneveket, amiket a lap tetején, és glosszázza őket olaszul:

$\begin{array}{ll}\text { nominativo } h(\mathrm{aec}) \text { buris, ris } & \text { a la coda del aratro } \\ \text { nominativo } h(\mathrm{aec}) \text { pelvis, vis } & \text { a la chonca } \\ \text { nominativo } h(\mathrm{aec}) \text { sitis, tis } & \text { a la sete } \\ \text { nominativo } h(\mathrm{aec}) \text { tussis, sis } & \text { a la tosse } \\ \text { nominativo } h(\mathrm{aec}) \text { caribdis, dis } & \text { a un scoglio marino }\end{array}$

A többi -im végủ főnév, és minden más morfológiai kategória bemutatása hasonlóképpen zajlik a grammatika hasábjain.

Látható ebből, hogy sem a tartalom, sem a szerkezet nem visz közelebb a szerző vagy possessor személyéhez, és a kódex posztillái és margináliái sem vezetnek el személyesen Vergerióhoz. A lényegi tartalom mellett ugyanis csupán a már említett levelet (f 104v) és az 1440-es betegségről szóló bejegyzést (f 108v) találjuk benne, valamint az utóbbival egy lapon még néhány tollpróbának tủnő latin mondást és egy ószláv betükkel írott szöveget.

Az f 108v lap bejegyzéseire a következő, a jelenlegi leírástól némiképp eltérő olvasatot adom:

Ante Deum stantes non sitis corde uagantes Quia si cor non orat, in vanum lingua laborat. Disce puer mores bonos ut fratres honores. Sus desceno (?) magis desceno (?) gaudet quam fonte sereno. Ego sum vitis vera $>$ ave a $<$ gaudet ecclesia. Ave Maria. 
$\mathrm{Az}$ „Ante Deum stantes non sitis corde uagantes” szállóigének tekinthető, amely, mint a katalógus is utal rá, ${ }^{10}$ a Grazer Universitätsbibliothek 1128 -as kódexében is szerepel. Az internet segítségével azonban hamar rábukkanhatunk ugyanezekre a szavakra például egy Pominóból Oxfordba vándorolt Antonius Florentinus-féle Confessionáléban (Oxford Bodleian Inc 335), melyben talán a gyóntatáshoz használt segédkönyvbe kézzel bejegyzett emlékeztetőről van szó. Szállóige tehát, amely a latin nyelvtanba akár példamondatként is kerülhetett.

A szöveg további közmondásokkal folytatódik, ám ezeknek a grammatikával való kapcsolata már teljesen esetlegesnek tünik. A harmadik sor (Disce puer...) tartalmát tekintve is illeszkedik egy tankönyvbe, de a negyedikkel problémába ütközünk. A latin mondás jelentése 'A koca jobban örül a sárnak, mint a tiszta víznek', ám itt hallomás vagy másolás alapján kettős hiba csúszott az idézetbe: a 'de coeno' helyett feleslegesen kétszer a nem létező 'desceno' szó serepel. A Csontosi-féle első leírásban a sus szó helyett jus olvasat áll, ${ }^{11}$ és így nem is volt megfejthető a mondás. Végül az utolsó két sor egy bibliai idézet eleje ('Én vagyok az igazi szőlőtő'), ám két liturgikus felszólítással folytatódik: 'Örvendjen az Egyház!', illetve 'Üdvöz légy Mária!'.

A kódex keletkezési helyének meghatározásához egyedül a latintól eltérő nyelvü bejegyzések adhatnak támpontot, ahogy a katalógus is említi: „Provenientia: Italia (e scriptura et orthographia et multae exempla Italica (cf. ff. 29'-30' sicut losengar, ingienochiar se etc.) videtur)". ${ }^{12}$ A kódex tartalma megfelel a korabeli latin nyelvtanoknak, ám ott, ahol a magyarázatot vagy a szó jelentését nem latinul adja meg (mint fentebb már láttuk), sok mindent elárul a készítőjéről, másolójáról és használójáról.

Példaként az adverbiumok felsorolását mutatom be (ff 71v-76v), mert ez a nyelvfejlődésnek olyan területe, ahol mind szerkezeti, mind alaki téren jelentős átalakulások történnek. A grammatika elsőként itt is definíciót ad arra, hogy mi a határozószó, majd egy hosszú lista következik:

$\mathrm{f} 71 \mathrm{v}$

\begin{tabular}{|l|l|}
\hline nunc & adeso \\
\cline { 1 - 2 } hodie & anchuo \\
\cline { 1 - 2 } heri & \multirow{2}{*}{ ieri } \\
\cline { 1 - 2 } pridie & doman \\
\hline cras & impusinam \\
\cline { 1 - 1 } perendine & \multirow{2}{*}{ novela mente } \\
\cline { 1 - 2 } nuper & \\
\cline { 1 - 2 } noviter &
\end{tabular}

${ }^{10}$ Catalogus... id. mü, 34.p.

${ }^{11}$ Csontosi János: A Konstantinápolyból... id. mủ, 199.p.

${ }^{12}$ Catalogus... id. mü. 34.p. 
Az adeso és novela szóalakok degeminációja észak-olasz változatot jelent, amint a doman szóalak szóvégi magánhangzójának hiánya is. E jelenségeket a továbbiakban nem emelem ki a szóalakokból, szinten minden lapon ismétlődnek. A 'ma' jelentésủ anchuo alak az ófrancia-óprovenszálból átvett ancoi variánsa, a Tesoro della Lingua Italiana delle Origini (TLIO) adatbankban egyszer fordul elö, egy velencei dokumentumban. ${ }^{13}$ A novela mente adverbiális forma két szóba írása tükrözi az újlatin adverbium-képzés analitikus voltát.

f $72 \mathrm{r}$

\begin{tabular}{|c|c|}
\hline aliquando & alguna fia \\
\hline tunc & in quela fia \\
\hline comdam & de qua in drie \\
\hline olim & ça gran tempo \\
\hline dudum & \multirow{2}{*}{ longo tempo } \\
\hline diu & \\
\hline iam & ça \\
\hline semper & sempre may \\
\hline cur & \multirow{5}{*}{ per che } \\
\hline quare & \\
\hline quam obrem & \\
\hline quasobres & \\
\hline quadere & \\
\hline non & \multirow{7}{*}{ no } \\
\hline nichil & \\
\hline nec & \\
\hline haud & \\
\hline minime & \\
\hline nequaquam & \\
\hline ne & \\
\hline utinam & \multirow{2}{*}{ dio volesse } \\
\hline amen & \\
\hline optato & \multirow{3}{*}{ desiderose mente } \\
\hline optate & \\
\hline optanter & \\
\hline
\end{tabular}

${ }^{13}$ A Pietro Beltrami professzor vezette Opera del Vocabolario Italiano projekt szabadon használható TLIO adatbankjának internetes elérhetősége: http://tlio.ovi.cnr.it/TLIO (2016. október 1.) 
A fia alak az 'alkalom' jelentésủ, valószínúleg szintén ófrancia jövevényszó, a fiata észak-itáliai változata: a TLIO mantovai, milánói, genovai szövegekben regisztrálja. Egyes szavak jelentését szinte szófordulatokkal adja vissza a kézirat szerzője: a semper fordítását (sempre) megtoldja egy nyomatékosító may adverbiummal, az amen és utinam szavak fordítása, dio volesse jelentése körülbelül 'adja Isten'. A de retrum-ból származtatható drie alakban is velencei jellegzetességeket azonosíthatunk, konkrétan isztriai szövegekben mutatja ki a TLIO.

f $72 \mathrm{v}$

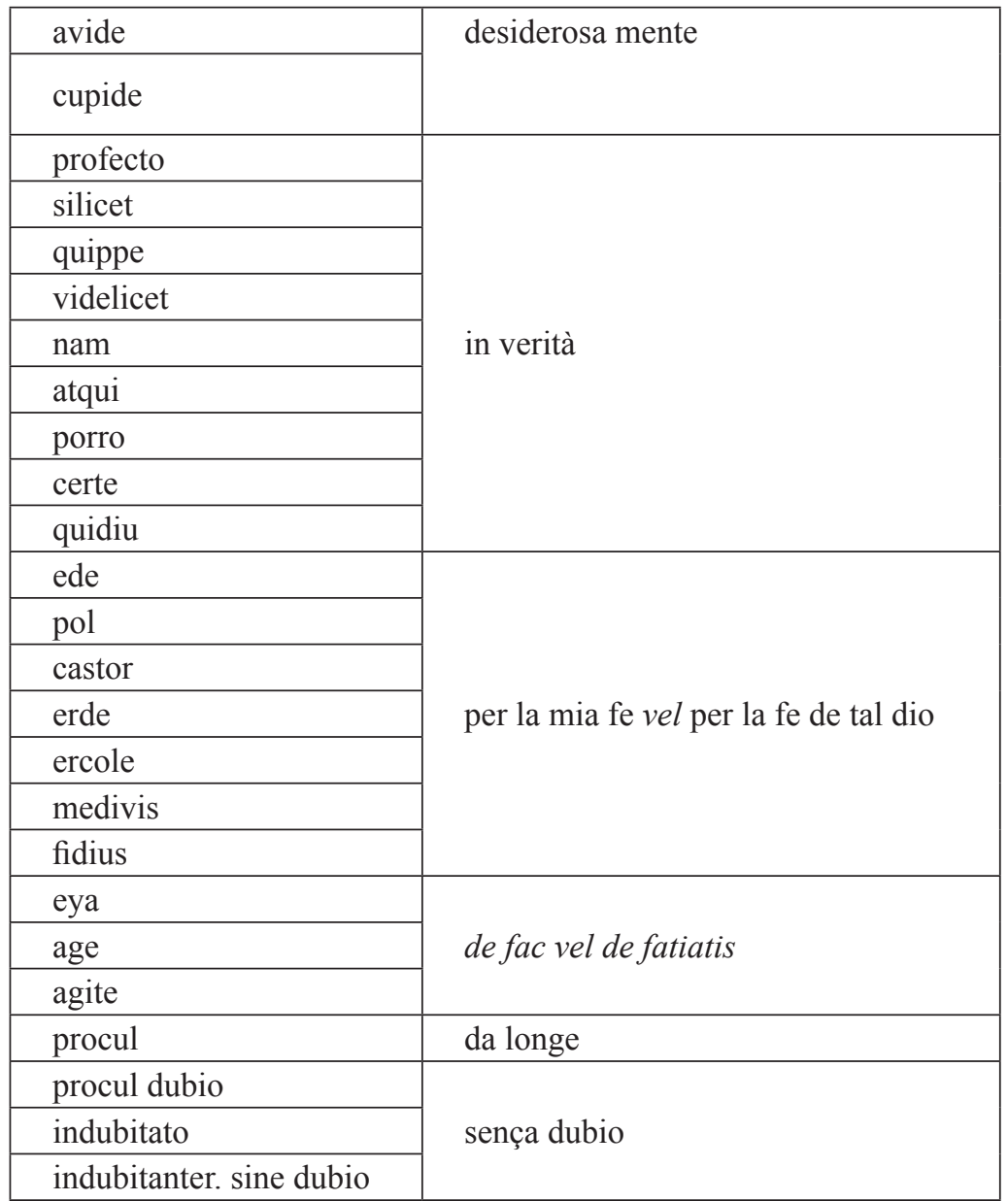

Az előző oldal végén és ennek a tetején 5 latin szinonímát sorol fel a 'remélhetőleg' jelentéshez. Ezen az oldalon a határozószavak között szerepelnek olyan indulatszavak is, amelyek a latin istenek nevéből származnak. Ezek fordításával nem sokat bajlódik a szerző, csak megjegyzi: 'hitemre vagy az adott isten hitére'. 
$\mathrm{f} 73 \mathrm{r}$

\begin{tabular}{|c|c|}
\hline vix & apena vel poco men \\
\hline paulatim & \multirow{2}{*}{$\begin{array}{l}\text { pienamente vel apuoco } \\
\text { apuoco }\end{array}$} \\
\hline paulatine & \\
\hline pede dentim & pepuspe vel tegnando pede \\
\hline comode & destra mente \\
\hline parce & temprade mente \\
\hline fere & \multirow{2}{*}{ puoco men } \\
\hline ferme & \\
\hline bene & ben \\
\hline male & mal \\
\hline docte & amaistrada mente \\
\hline pulcre & bella mente \\
\hline fortiter & forte mente \\
\hline suaviter & suave mente \\
\hline inpune & sença pena \\
\hline integraliter & intriega mente \\
\hline sane & sana mente \\
\hline liquide & \multirow{3}{*}{ manifesta mente } \\
\hline liquido & \\
\hline manifeste & \\
\hline rationabile & \multirow{3}{*}{ rasonivel mente } \\
\hline merito & \\
\hline meritorie & \\
\hline inrationaliter & \multirow{3}{*}{$\begin{array}{l}\text { non rasonivel mente vel sença } \\
\text { rason }\end{array}$} \\
\hline inmerito & \\
\hline demeritorie & \\
\hline
\end{tabular}

Erről az oldalról velencei szóként kiemelhető a docte megfelelőjeként az amaistrada mente, amely felbukkan például az Egyetemi Könyvtár Dante-kódexének függelékében is, egy XIV. századi latin-velencei kétnyelvű szólásgyüjteményben, amely Albertano da Brescia egy traktátusának kivonata. ${ }^{14}$ Ugyancsak

${ }^{14}$ Domokos György - Vida Máté: A budapesti Dante-kódex nyelve. = Egyetemi Könyvtár Évkönyvei. 12. köt. Budapest, ELTE Egyetemi Könyvtár. 2005. 35-60. p.; Domokos György: Il volgarizzamento veneto del Liber de amore di Albertano da Brescia in appendice al codice 
velencei szónak tekinthetjük a rason szót, a latin ratio megfelelőjét, amely itt több adverbium fordításában is szerepel. Érdekes kontaminációt mutat a pede dentim, ami valószínüleg a 'szorosan nyomonkövetve' jelentésü pedetemptim, pedetentim népi etimológiával elferdített változata.

f $73 \mathrm{v}$

\begin{tabular}{|c|c|}
\hline multum & molto \\
\hline parum & \multirow{2}{*}{ puoco } \\
\hline modicum & \\
\hline nimium & tropo \\
\hline satis & asai \\
\hline maxime & granda mente \\
\hline forsam & \multirow{4}{*}{ forse } \\
\hline forsitan & \\
\hline fortassis & \\
\hline fortasse & \\
\hline forte & \multirow{3}{*}{ per aventura } \\
\hline fortuitu & \\
\hline a casu & \\
\hline simul & \multirow{4}{*}{ insembre } \\
\hline una & \\
\hline pariter & \\
\hline adinvicem & \\
\hline festinanter & \multirow{8}{*}{$\begin{array}{l}\text { affreçada mente vel viagia } \\
\text { mente }\end{array}$} \\
\hline accelerate & \\
\hline celeriter & \\
\hline properanter & \\
\hline propere & \\
\hline velociter & \\
\hline concite & \\
\hline subito & \\
\hline
\end{tabular}

Ezen az oldalon szembeötlő az insembre szóalak, a mai toszkán-olasz insieme, 'együtt' adverbium változata, amely a francia ensemble hatása nélkül nehezen képzelhető el; Dante és Ariosto müveiben is előfordul. Az afreçada és viagia melléknévi alakok 'gyors' jelentéssel ugyancsak a venetói nyelvjárásokhoz köthetők.

dantesco. $=$ Dante Alighieri Commedia. Budapest Biblioteca Universitaria Codex Italicus 1. II. kötet: Studi e ricerche. Szerk. Pál József - Marchi, Gian Paolo. Verona, Szegedi Tudományegyetem - Universtità degli Studi di Verona. 2006. 99-116. p. 
$\mathrm{f} 74 \mathrm{r}$

\begin{tabular}{|c|c|}
\hline evestigio & \multirow{5}{*}{$\begin{array}{l}\text { affreçada mente vel viagia } \\
\text { mente }\end{array}$} \\
\hline extemplo & \\
\hline cumsubito & \\
\hline confestim & \\
\hline repente & \\
\hline mutuo & \multirow{4}{*}{$\begin{array}{l}\text { l'un con l'altro o mo l'un mo } \\
\text { l'altro }\end{array}$} \\
\hline alternantim & \\
\hline vicesim & \\
\hline alterutrum & \\
\hline regulariter & regular mente \\
\hline inregulatirer & \multirow{2}{*}{$\begin{array}{l}\text { non regular mente vel fuora } \\
\text { de rason }\end{array}$} \\
\hline enormiter & \\
\hline sordide & \multirow{2}{*}{ soça mente } \\
\hline turpe & \\
\hline dure & \multirow{2}{*}{ dura mente } \\
\hline duriter & \\
\hline plene & \multirow{2}{*}{ piena mente } \\
\hline penarie & \\
\hline latenter & \multirow{6}{*}{ aliegra mente } \\
\hline letabiliter & \\
\hline gaudiose & \\
\hline gaudenter & \\
\hline alacriter & \\
\hline ylarie & \\
\hline etiam & anche \\
\hline
\end{tabular}

A $74 \mathrm{r}$ lapon a 'most' jelentésủ mo alakot emelhetjük ki, amely a latin modo-ból származik. A 'felváltva' jelentésủ alternantim latin adverbiumot két körülírással tudja csak megadni a szerzö: l'un con l'altro, vagyis 'egyik a másikkal', illetve mo l'un mo l'altro, vagyis 'hol az egyik, hol a másik'.

$\mathrm{f} 74 \mathrm{v}$

\begin{tabular}{|l|l|}
\hline gradatim & de grado in grado \\
\hline annuatim & de anno in anno \\
\hline menstruatim & de mese in mese \\
\hline dietim & de dì in dì \\
\hline hostiatim & de porta in porta \\
\hline
\end{tabular}




\begin{tabular}{|c|c|}
\hline viritim & de homo in homo \\
\hline legaliter & lial mente \\
\hline item & \multirow{3}{*}{ anchora } \\
\hline aduc & \\
\hline rursus & \\
\hline nondum & \multirow{2}{*}{ non anchora } \\
\hline nonaduc & \\
\hline preterea & infra tanto \\
\hline non solum & \multirow{3}{*}{ non sola mente } \\
\hline nonsolumodo & \\
\hline nontantomodo & \\
\hline ordinatim & \multirow{3}{*}{ ordenada mente } \\
\hline seriose & \\
\hline seriatim & \\
\hline inordinate & desordenada mente \\
\hline nominaliter & \multirow{2}{*}{ per nome } \\
\hline nominatim & \\
\hline ubique & \multirow{2}{*}{ in hogni luogo } \\
\hline ubicumque & \\
\hline sollicite & sollicita mente \\
\hline
\end{tabular}

A 'fokról fokra', 'évről évre', 'hónapról hónapra' stb. jelentésủ adverbiumok megfelelője ismét csak körülírással lehetséges. Az ortográfiai norma hiányát mutatják a velencei glosszák, ezen az oldalon például a mai írásmódtól eltérő anchora (ancora) és hogni (ogni) alakok.

f $75 \mathrm{r}$

\begin{tabular}{|l|l|}
\hline atente & atenta mente \\
\hline antique & antiga mente \\
\hline antiquius & più antiga mente \\
\hline interim & \multirow{2}{*}{ infra tanto } \\
\hline interea & \multirow{2}{*}{ de l'una parte e d'altra } \\
\cline { 1 - 1 } utrinque & \multirow{2}{*}{ perpetual mente } \\
\cline { 1 - 1 } perpetue & \\
\cline { 1 - 1 } perpetuo & niente men \\
\cline { 1 - 2 } perhenim &
\end{tabular}




\begin{tabular}{|l|l|}
\hline ex quo & \multirow{2}{*}{ da posa } \\
\cline { 1 - 1 } postquam & entro li parlanti \\
\hline inter loquentes & almen \\
\hline saltem & saltando \\
\hline saltim & \multirow{2}{|c|}{ esser stado } \\
\cline { 1 - 1 } saltim saltando sed saltem dic minuendo \\
\hline asatise & \multirow{2}{*}{ divisa mente } \\
\cline { 1 - 1 } secus & \\
\cline { 1 - 1 } seorsus & \\
\cline { 1 - 1 } separatim & \\
\cline { 1 - 1 } secreto & \\
\cline { 1 - 1 } divisim &
\end{tabular}

A f 75r lapon olvasható alakok alapján megállapítható, hogy az észak-olasz nyelvfejlődésre egészen a mai dielaktusokig jellemző magánhangzók közötti zöngésedés több alakot is érint: antiga (antica) és stada (stata).

f $75 \mathrm{v}$

\begin{tabular}{|c|c|}
\hline trifariam & \multirow{2}{*}{ divisa mente } \\
\hline multifariam & \\
\hline quasi & \\
\hline ceu & \multirow{10}{*}{ cuscì } \\
\hline sic & \\
\hline sicut & \\
\hline sicuti & \\
\hline velud & \\
\hline veluti & \\
\hline ut & \\
\hline uti & \\
\hline ita & \\
\hline tale & \\
\hline inde & \multirow{4}{*}{ da possa } \\
\hline de inde & \\
\hline de inceps & \\
\hline continuo & \\
\hline protinus & da longe vel a postuto \\
\hline propterea & imperò \\
\hline
\end{tabular}




\begin{tabular}{|l|l|}
\hline albius & più biancha mente \\
\hline nigrius & più negra mente \\
\hline doctius & più amaistrada mente \\
\hline fortius & più forte mente \\
\hline sapientius & più savia mente \\
\hline solicius & \multirow{2}{*}{ più solicita mente } \\
\cline { 1 - 2 } actentius & \\
\hline
\end{tabular}

Ezen a lapon több fokozott határozószó is található, a fordítás megfelel a modern olasz szerkezetének, ám ezt három szóban írja a szerző. Meglepő a mai déli dialektusokra jellemző cuscì 'így' alak felbukkanása, és a 'később' jelentésnek megfelelö possa alak sem dokumentált a TLIO adatbázisban.

$\mathrm{f} 76 \mathrm{r}$

\begin{tabular}{|c|c|}
\hline plus & nì̀ \\
\hline magis & piu \\
\hline minus & men \\
\hline $\tan$ & tantum \\
\hline quam & quantum \\
\hline maxime & grandissima mente \\
\hline doctisime & più amaistrada mente \\
\hline fortissime & fortissima mente \\
\hline albissime & biancha mente \\
\hline semel & una fia \\
\hline bis & do fia \\
\hline ter & tre fia \\
\hline quater & quatro fia \\
\hline quinquies & çinque fia \\
\hline sexies & sae fia \\
\hline septies & sete fia \\
\hline octies & oto fia \\
\hline novies & nove fia \\
\hline deties & diesci fia \\
\hline centies & cento fia \\
\hline millies & mille fia \\
\hline tonciens & tante fia \\
\hline quociens & quante fia \\
\hline multociens & molte fia \\
\hline meatim & a mio modo \\
\hline
\end{tabular}


Az adverbiumok között találjuk itt felsorolva a felsőfokú alakokat, bár a latin doctisime megfelelőjeként a szerző a középfokot jelentő più amaistrada mente alakot adja meg, ugyanazt, amit az előző lapon a középfojú doctius esetén. Utána számnevekből képzett határozószók sorjáznak, a már említett fia 'alkalom' jelentésü főnév segítségével körülírással.

f $76 \mathrm{v}$

\begin{tabular}{|c|c|}
\hline tuatim & a tuo modo \\
\hline suatim & a suo modo \\
\hline nostratim & a nostro modo \\
\hline vestratim & a vestro modo \\
\hline clam & \multirow{3}{*}{ ascosa mente vel piena mente } \\
\hline culum & \\
\hline belle & \\
\hline heus & \multirow{2}{*}{ „ella” clamare } \\
\hline hoo & \\
\hline heu & \multirow{2}{*}{ „o ben” respondere } \\
\hline ey & \\
\hline latenter & \multirow{2}{*}{ ascosa mente } \\
\hline oculte & \\
\hline licet & \multirow{2}{*}{ avegna dio } \\
\hline quamvis & \\
\hline ultra & \multirow{2}{*}{$\begin{array}{l}\text { oltra sed reperuit } \\
\text { prepositiones }\end{array}$} \\
\hline trans & \\
\hline decetero & \multirow{2}{*}{ da mo avanti } \\
\hline posterum & \\
\hline funditus & infina al fondo \\
\hline inprovise & \multirow{3}{*}{ desaviçuda mente } \\
\hline inproviso & \\
\hline inprovide & \\
\hline interim & \multirow{2}{*}{ infra tanto } \\
\hline interea & \\
\hline
\end{tabular}

Az adverbiumok hasznos szótárának utolsó lapján a módhatározók után érdekes módon a megszólítás és reagálás formulái szerepelnek. A heus és hoo megfelelöjének a szerző saját nyelvén az ella szót tartja, az erre való válasz latinul heu vagy ey, amit $o$ ben fordítással ad át. A desaviçuda mente alak 'hirtelen' jelentésü melléknévi elemét szintén ismerhetjük a Cod. Ital. 1 Albertano-szövegéből.

A fenti rövid tanulmány arra kívánja ráirányítani a figyelmet, hogy a kéziratok, kódexek keletkezési helyének és idejének meghatározásában milyen fontos szerep 
jut a nyelvi formák elemzésének. A latin nyelvtankönyvet tartalmazó Cod. Lat. 23, amelyet hagyományosan Vergerio-kódexként ismerünk, Itáliából származik, ahol a vulgáris nyelv térbeli és időbeli rétegzettsége szolgáltatja a legerősebb bizonyítékot, hogy a könyv a XIV-XV. századi velencei nyelv hatása alatt készült.

\section{Rezümé}

A ELTE Egyetemi Könyvtár Cod. Lat. 23 jelzetü kódexének Pier Paolo Vergerio személyéhez való kapcsolása olyan bizonyítékokon alapul, amelyek nem tekinthetök teljesen perdöntőnek. Ugyanakkor a kódex nem latin nyelvű bejegyzéseinek elemzése egyértelmủen bizonyítja a kézirat velencei származását.

\section{The 'Vergerio Grammar' of the ELTE University Library}

(Cod. Lat. 23)

The 'Vergerio Grammar' of ELTE University Library is linked to the person of Pier Paolo Vergerio by proofs that can't be regarded as fully certain. However the analyses of the language of Cod. Lat. 23 shows without doubt that the manuscript came from the area of Venice.

DOMOKOS GYÖRGY egyetemi docens PPKE BTK Olasz Tanszék 